kluczową dziś kwestię współuczestnictwa dzieci i młodzieży w obszarze relacji $\mathrm{z}$ nauczycielami i rodzicami. Chałasiński przestrzegał wówczas przed zawężaniem tego problemu, „dostrzegał przemijanie zarówno $w$ teorii, jak i w praktyce edukacyjnej problemów współpracy uczniów z nauczycielami, dzieci z rodzicami i młodzieży z dorosłymi w ogóle" (s. 228 - 229). Dzisiaj gdy relacja pedagogicznego współdziałania próbuje przełamywać w teorii i praktyce różnych rodzajów stosunków pedagogicznych (w tym rodziny i szkoły) opory wobec autentycznego partnerstwa dorosłych i dorastajacych, warto do tych myśli i koncepcji sprzed pięćdziesięciu lat powrócić, a niektóre $\mathrm{z}$ nich przemyśleć na nowo.

Jak widać lektura książki Krzysztofa Jakubiaka nie skłania do odłożenia pracy na półkę. Jest to bowiem propozycja intelektualnie płodna $\mathrm{i}$ twórczo inspirująca. Stwarza nie tylko możliwości „rozmowy” z faktami i Autorem, ale także zaznacza swoiście praktyczną użyteczność. Odegra z pewnością istotną rolę w procesie edukacji nauczycielskiej, lecz kto wie czy nie większe znaczenie mieć będzie dla działacza oświatowego czy światłego rodzica. Wszystko zależy od tego czym są dla nas dzisiaj stosunki rodziny i szkoły. Dla Autora książki wydają się być one kluczem odsłaniającym inną, bo bardziej demokratyczną i humanistyczną, optyke ujmowania i rozwiązywania kwestii edukacyjnych. Jestem zdecydowanie po Jego stronie. Pół wieku temu Stanislaw Lisowski wspaniały uczeń wspaniałego pedagoga - Marii Grzegorzewskiej napisał odważnie: „Reforma szkoły właściwie od rozwiązania zagadnienia współpracy domu i szkoły zaczynać się powinna" (Wspólpraca szkoly z domem, NK, Warszawa 1935 , s. 43). Nie znam próby podjęcia tego wyzwania. Podzielam jednak przekonanie tych, którzy spodziewają się w nadchodzącym stuleciu „zwrotu ku czlowiekowi i rodzinie”. Być może wówczas realizacja tego śmiałego postulatu okaże się nie tylko możliwa, ale i efektywna.

Krzysztof Jakubiak w zakończeniu książki formułuje - czyniąc analogie do współczesności - skromną sugestię i proponuje czytelnikowi by uświadomił sobie, „czy myśl innych nie biegła przed laty po podobnych torach". Zdołał w moim przekonaniu tego dowieść. Czy jednak bardziej nie fascynuje niewiadoma dokad owa mysl moglaby nas zaprowadzic?. Nie tylko $\mathrm{z}$ tego powodu warto się prezentowaną tu publikacją zainteresować.

Andrzej W. Janke

\title{
Danuta Koźmian, Chrześcijańska myśl wychowawcza Fryderyka Wilhelma Foerstera i jej recepcja w Polsce, Wydawnictwo Uniwer- sytetu Szczecińskiego, Szczecin 1996, ss. 169
}

W powojennej historiografii pedagogicznej brakowało dotychczas źródłowego, krytycznego opracowania monograficznego, poświęconego postaci i twórczości Fryderyka Wilhelma Foerstera (1869 - 1966). Książka Danuty Koźmian wypehia tę lukę. Jest ona pierwszą, wydaną po II wojnie światowej rozprawą, która w sposób całościowy ukazuje sylwetke, życie i dorobek tego wybitnego niemieckiego filozofa, pedagoga i moralisty. Autorka dokonuje także udanej próby określenia wpływu pedagogiki F.W. Foerstera na wychowanie chrześcijańskie w Polsce. Celem tej pracy jest bowiem nie tylko dokonanie analizy $\mathrm{i}$ interpretacji myśli wycho- wawczej Foerstera, dotyczącej zwłaszcza wychowania moralnego i obywatelskiego, ale także przedstawienie jej recepcji w Polsce w pierwszej połowie XX wieku oraz określenie możliwości jej wykorzystania we współczesnej pedagogice.

Strukture pracy wyznacza sześć zasadniczych rozdziałów, w ramach których w układzie problemowym, Autorka poddała wszechstronnej analizie historyczno-pedagogicznej wiele szczegółowych zagadnień. W rozdziale pierwszym została ukazana tradycja społecznej i edukacyjnej działalności Kościoła katolickiego w Polsce, ze szczególnym uwzględnieniem jego roli w pracach społeczno-integracyjnych w na- 
szym kraju. Rozdział drugi jest próbą analizy pedagogiki religijnej i jej związków z głównymi doktrynami pedagogicznymi II Rzeczypospolitej: wychowaniem narodowym i wychowaniem państwowym oraz "nowym wychowaniem".

W rozdziale trzecim Autorka przedstawiła biografię, działalność społeczno-religijną oraz twórczość pisarską F.W. Foerstera. W kolejnych dwóch rozdziałach konsekwentnie prezentowane są poglądy Foerstera dotyczące religii i jej znaczenia w kształtowaniu charak teru człowieka, reformy pedagogiki religijnej oraz zadań w zakresie wychowania moralnego wychowawców, kapłanów i rodziców, a także nowego ujęcia wychowania obywatelskiego i państwowego. Autorka odnotowała tu także stosunek Foerstera do tzw. „szkoły tradycyjnej” oraz „nowego wychowania" $i$ idei samorządności uczniowskiej. W rozdziale szóstym zawarto próbę analizy recepcji chrześcijańskiej myśli wychowawczej Foerstera w Polsce, szczególnie w piśmiennictwie, wyróżniając w tym procesie okres zaborowy, międzywojenny oraz okupacje hitlerowską. Trafnie i umiejętnie poglądy pedagogiczne Foerstera $i$ ich recepcje, rozpatrywano w szerszym kontekście społecznej i edukacyjnej roli Kościoła oraz na tle kształtowania od początku XX wieku chrześcijańskiej myśli pedagogicznej.

Praca D. Koźmian jako monografia historyczno-pedagogiczna, dzięki zastosowanym metodom badawczym, ma walory pracy biograficznej, uwzględniającej także zasady monografii psychologicznej. Autorka w swych badaniach wykorzystała zarówno źródła archiwalne, drukowane oraz obszerną literature przedmiotu, w tym także prace autorów niemieckich. Calokształt materialów źródlowych oddaje skrupulatnie sporządona bibliografia.
Dobrze się stało, że Danuta Koźmian poświęciła kilka ostatnich lat swojej pracy badawczej przybliżeniu czytelnikom mało znanego we współczesnej polskiej literaturze dorobku pedagogicznego F.W. Foerstera. Tym bardziej, że w okresie międzywojennym jego dzieła cieszyły się zasłużona ogromną popularnością, - czym świadczy choćby odnotowany przez Autorkę fakt przetłumaczenia wówczas na język polski 19 prac Foerstera oraz częstego ich cytowania przez polskich pedagogów.

D. Koźmian wyraża w swej książce słuszne przekonanie, że przypomnienie twórczości tego wybitnego wychowawcy i moralisty może wnieść niejedną nową myśl do rozważań nad współczesną pedagogika, zorientowaną nie tylko na światopogląd chrześcijański. W ostatniej części swej pracy Autorka takiej właśnie próby z powodzeniem dokonuje.

Monografia D. Koźmian napisana $z$ dużą erudycją, ładną polszczyzną, zwarta i logiczna zasluguje na uwage i spetnia oczekiwania nie tylko historyków wychowania. Żałować jedynie należy, że ta wzorowo przygotowana pod względem merytorycznym, metodologicznym i edytorskim praca, pozbawiona jest indeksu nazwisk oraz wydana zostala w zbyt skromnym nakładzie, zaledwie 200 egzemplarzy. Nie zaspokoi on nawet podstawowych potrzeb środowiska naukowego historyków wychowania, nie mówiąc już o licznym gronie osób studiujących historię, nauki pedagogiczne i filozofię. Należy więc postulować i liczyć na szybkie wznowienie przez Wydawnictwo Uniwersytetu Szczecińskiego tej cennej i pożytecznej książki.

Krzysztof Jakubiak

\section{Pedagogika ogólna. Tradycja - teraźniejszość - nowe wyzwania (materialy pokonferencyjne), red. Teresa Hejnicka-Bezwińska, Wy- dawnictwo Uczelniane WSP, Bydgoszcz 1995, ss. 329}

Licząca bez mała dwa wieki - jeżeli przyjąć, że po raz pierwszy termin „pedagogika ogólna" pojawił się dzięki Johannowi F. Herbartowi $^{1}$ - tradycja uprawiania ogólnej teorii wychowania zaowocowała wielością koncepcji, wizji, propozycji, pomysłów dotyczących tego, co stanowi przedmiot owej dyscypliny. Wielość tę dobrze odzwierciedla bogactwo terminów, 